\title{
What drives public acceptance of reforms? Longitudinal evidence from a Dutch pension reform
}

\author{
Jante Parlevliet ${ }^{1,2}$ (D)
}

Received: 4 April 2016/Accepted: 29 March 2017/Published online: 9 September 2017

(C) The Author(s) 2017. This article is an open access publication

\begin{abstract}
Governments often find it hard to pursue economic reforms, even if they eventually will benefit a majority of voters. The literature remains inconclusive about the reasons for this. Some scholars, on the one hand, stress the role of distributional conflicts between different classes, for instance dividing the young and the old in the case of pay-asyou-go pensions. Others have highlighted that resistance to reform is rather broad-based owing to the public's poor understanding of the need for reform. This paper attempts to disentangle the drivers of public acceptance of reform by means of a case study: the 2012 increase of the Dutch statutory retirement age from 65 to 67 . We exploit a unique longitudinal dataset on the attitudes of Dutch households respecting pension reform in the 2003-2013 period. Our findings offer various new insights. First, we find that education, occupational status and psychological traits were the most systematic drivers of reform preferences, while age had a limited impact. Second, and significantly, we find that the year fixed effects were the main drivers of respondents' acceptance of reform. We interpret the pattern of the year coefficients as evidence of a collective learning process whereby households gradually updated their expectations and reform preferences in light of new information.
\end{abstract}

Keywords Pension reform $\cdot$ Political economy $\cdot$ Public opinion · Information

JEL Classification D72 - D83 - H55 - P16

Electronic supplementary material The online version of this article (doi:10.1007/s11127-017-0447-7) contains supplementary material, which is available to authorized users.

Jante Parlevliet

j.parlevliet@dnb.nl

1 De Nederlandsche Bank, Amsterdam, Netherlands

2 University of Amsterdam, Amsterdam, Netherlands 


\section{Introduction}

Governments often find it hard to pursue economic reforms. Two general sets of considerations have been put forward to explain this. A first view points toward distributional conflicts between different socio-political groups with opposing interests. Such conflicts can take time to be resolved because, for instance, it can pay to outwait the other party in a 'war of attrition' (see, e.g., Alesina et al. 2006). By the same token, reforms can be blocked owing to opposition by powerful groups that have much to lose from these reforms (Olson 1965; Sinn and Uebelmesser 2002). A second view stresses that resistance to reforms is in fact rather broad-based. In particular, universal welfare programs tend to be rather popular with large numbers of the electorate (Pierson 1996; Brooks and Manza 2006; Vis 2016) and the public may often not appreciate that reforms are necessary (Boeri et al. 2001, 2002; Blinder and Krueger 2004; Caplan 2007). In this context, voters who eventually gain may resist change (Pitlik et al. 2014). Governments therefore may be reluctant to propose reforms because of expected electoral risks. In the purported words of former Eurogroup president Juncker, "We all know what to do but we don't know how to be re-elected once we have done it" (The Economist 2007, quoted in Buti et al. 2008).

This paper aims to disentangle the role of individual-level and collective resistance to reform using a case study of a major Dutch policy change implemented in 2012, namely raising the statutory retirement age from 65 to 67 in 2023. From the perspective of policymakers, this reform measure increasingly was seen as the most promising option for adjusting the public pay-as-you-go (PAYG) pension system to the Dutch population's ageing (as in other countries; see World Bank 1994). The same rise in retirement age already had been considered at the scheme's inception in 1957, and advocated by policy committees in the 1980s and 1990s. Nevertheless, it was politically controversial (as it is and was elsewhere in Europe; see Arza and Kohli 2008; Eurobarometer 2012), and various governments instead resorted to more passive measures, such as raising payroll taxesand, since the late 1990s, transfers from the general budget - and temporary suspensions of the indexation of benefits. Building on a unique longitudinal dataset over the years 2003-2013, we evaluate the explanatory powers of the expectations and preferences of Dutch households towards a later retirement age in the run-up to the actual reform. Controlling for a large set of covariates, we assess the extent to which opposition to the reform was driven by various individual characteristics—-such as age and income —or was broader in nature.

Our analysis makes two contributions to the literature. First, given information on a large set of individual characteristics and a large number of observations (over 12,000) our data enable us to assess systematically the relative importance of various explanatory variables that have been suggested in the literature, such as age, employment status, income, demographic factors, education and deeper-rooted psychological traits. Second, the time dimension of our data is unique and enables us to trace preferences for reform over a time span of ten years in the run-up to an actual reform. This time dimension turns out to play a critical role.

Our most important findings can be summarized as follows. First, among the individual covariates, we find that education, psychological traits (such as patience and locus of control) and employment status were the most robust drivers of acceptance of the reform. On the other hand, despite the diverging interests of young and old respondents, age explains only a minor share of the variation in reform attitudes. We also do not find that income played a significant role in attitudes toward pension reform, even though the PAYG 
schemes entails considerable redistribution across income groups. Second, we find that the year fixed effects in our regression are dominant in driving respondents' acceptance of the reform. In the ten years preceding the reform, households seem gradually to have updated their expectations and preferences in light of new information and political debates (e.g., public discussions concerning the ending of early retirement schemes). This evidence suggests that distributional and generational clashes were not at the heart of the observed resistance to raising the retirement age.

The next section presents an overview of the factors the literature has proposed as driving attitudes to policy reforms, focusing on PAYG pensions. Section 3 describes the Dutch pension system and the most important phases in the reform process, while Sect. 4 describes our data. Section 5 discusses our results. Given the important role of time, Sect. 6 will inspect the coefficients of our year dummies, qualitatively linking them to some key events in the reform process. After several robustness checks in Sects. 7, 8 concludes.

\section{Literature on the political economy of pension reform}

A large theoretical and empirical literature has highlighted a variety of factors that shape individuals' attitudes towards PAYG pension reform. While some authors examine support for raising the retirement age specifically (Van Els et al. 2003; Cremer et al. 2008; Scheubel et al. 2013), most studies have considered reforms that reduce the amounts of PAYG transfers. These reforms are of course related: when the level of benefits is kept unchanged, postponing the retirement age also reduces PAYG transfers. However, in at least two respects raising the retirement age differs fundamentally from other reform margins (larger contributions or smaller benefits). First, for these options to be identical even in an actuarially neutral system, ${ }^{1}$ strong assumptions have to be made about the consistency and stability of household preferences and households' use of all available information, conditions that are not easily met (Fatas et al. 2007). Second, and relatedly, several studies have confirmed that the statutory retirement age acts as an important 'focal point' for actual retirement decisions (see, e.g., Behaghel and Blau 2012 for the United States and Vermeer et al. 2014 for The Netherlands). For some households, following the accepted practice even entails significant economic costs (Lumsdaine et al. 1996). Where relevant, we therefore adapt the arguments in the literature to a context wherein the retirement age has a particular 'reference role' for retirement decisions. Below, we will in turn discuss the roles of age, employment status, income, demography, ideology, education, knowledge and the political process itself.

Age plays the predominant role in political economy models addressing the reform of PAYG pensions (for a review, see Galasso and Profeta 2002). In the case of demographic pressures on the PAYG scheme, young workers might be less willing to support a retirement program from which they themselves might not benefit. However, because the old grow in number as the population ages, they can block reforms by majority voting (e.g., Sinn and Uebelmesser 2002) or by lobbying activities (Mulligan and Sala-i-Martin 1999). On the basis of surveys among Italian, Spanish, French and German respondents, Boeri et al. $(2001,2002,2012)$ report that the young are indeed more keen to make PAYG pensions less generous, although not all of the evidence is unambiguous (Blinder and

${ }^{1}$ Cremer et al. (2008) furthermore show that as soon as a PAYG system entails redistribution, such as in The Netherlands, it is unavoidable that the system includes distortions towards early retirement. 
Krueger 2004; Kohli 2008; Eurobarometer 2012). On the basis of a 2003 survey in The Netherlands, Van Els et al. (2003) find that support for raising the retirement age was weak overall, while respondents' ages had no significant impact on such support.

Of course, age is only one factor that determines one's stake in PAYG systems and income and employment status are also likely to be important. As to the former, flat-rate PAYG systems entail a substantial within-cohort redistribution; such is the case in The Netherlands (Bonenkamp and Ter Reele 2013). Higher-income respondents therefore would be better off when the scheme becomes less generous (Tabellini 2000). Similarly, one's labor market status is expected to influence preferences towards pension reform (see, e.g., Drissen and Van Winden 1991). Empirical evidence has confirmed this (e.g., Boeri et al. 2001, 2002, 2012; Blinder and Krueger 2004). Boeri et al. (2001, 2002), however, find mixed results for the effects of income.

Demographic factors also can shape preferences for pension reforms because decisions on retirement often are made in a family context (Leroux et al. 2011; Vermeer et al. 2014). Indeed, empirical studies have confirmed that married respondents are less supportive of pension reform (see, e.g., De Grip et al. 2011; Boeri and Tabellini 2012). Furthermore, other studies have found that women are less likely to favor pension reforms that reduce public transfer payments (Boeri et al. 2002; Blinder and Krueger 2004; Boeri and Tabellini 2012; Scheubel et al. 2013). Having children or grandchildren might also matter. Goerres and Tepe (2010) find that older respondents are more likely to support public child-care provision-which they pay for, but will not use-if they are in close contact with their adult children. Likewise, people with grandchildren could be more likely to value the future sustainability of public pension programs. Finally, support for pension reform may also depend on respondents' health status (McGarry 2002; Scheubel et al. 2013).

Empirical studies of attitudes towards pension reform also often include a self-reported measure of ideology on the left-right scale. Boeri et al. $(2001,2002)$ find that political ideology systematically drives preferences for reform; Blinder and Krueger (2004) even conclude that ideology is the main factor underlying reform preferences. Ideology can be a rational basis for voting as it can simplify choices in the context of a multidimensional issue space. Most obviously, left-wing parties typically are seen to cater to the working class (although, according to some, this class divide has become less pronounced; see, e.g., Jansen et al. 2013). Recent research also has found that deep-rooted psychological traits influence ideological positions, which are sometimes at odds with economic self-interest (see Jost et al. 2011; Gerber et al. 2011). For instance, studies have shown that individuals that rank high on 'conscientiousness' - the extent to which people think of themselves as organized and keeping their promises, one of the so-called 'Big Five' personality traitstend to be more conservative, both in social and economic terms. Although still in its infancy, this strand of literature links such traits directly to political attitudes and outcomes. For example, Alesina and La Ferrara (2005) hypothesize and confirm empirically that risk averse individuals in a US sample value redistribution more than others do (see also Verbon and Van Winden 1985). Furthermore, on the basis of both the US and World Values Survey, Alesina and Giuliano (2009) find that respondents who believe that luck is a more important driver of success than hard work, have stronger preferences for redistribution. These results are corroborated by Kouba and Pitlik (2014).

Empirical studies typically also find that education helps explain preferences for pension reform, holding income constant (see, e.g., Boeri et al. 2001). Education might influence preferences for pension reform through several channels. More highly educated individuals might enjoy greater job satisfaction and might be more optimistic about their future employment prospects (Scheubel et al. 2013). Another factor correlated with 
education is knowledge about the pension system. When respondents simply are unaware of rising pressure on the public pension system ('fiscal illusion') because, for instance, they do not realize that employers offer lower wages to help finance their own contributions to the program, they might well support the status quo of a stable retirement age and stable benefits, even if that is at odds with their interests (Browning 1975; Cremer and Pestieau 2003). Boeri et al. (2001, 2002) confirm that households underestimate the costs of public pensions, sometimes quite dramatically so.

Households' lack of knowledge creates opportunities for policymaking discretion. In the more stylized median voter models politicians merely mirror the preferences of their constituencies in order to maximize their votes. Yet, political elites can be expected to have better information on the urgency of budgetary pressures than the electorate does and, as such, can support unpopular policies (see, e.g., Pierson 1996; Cukierman and Tommasi 1998). At the same time, of course, politicians seek votes. The fact that retrenchment of broadly valued welfare programs happens nonetheless, has inspired a large body of literature on the conditions under which governments can overcome resistance to reforms, such as 'blame avoidance' and careful framing of the need for reform (see, e.g., Pierson 1996; Cox 2001; Green-Pederson 2002; Arza and Kohli 2008; Vis 2016). Elected public officials and bureaucrats may influence the reform process. On the one hand, bureaucrats can hamper reforms when, for instance, they are motivated to maximize their budgets (Niskanen 1971). For the US social security program, Congleton and Shughart (1990) find that the scope for budget-maximization of PAYG is limited, given the relatively simple and transparent structure of its administration. On the other hand, bureaucrats can facilitate reforms when elected politicians use them to avoid the blame for unpopular measures, as in the case of Sweden (Marier 2005). In The Netherlands, politicians used a similar strategy to reform the disability insurance scheme by, e.g., referring to reports by independent agencies and by delegating programmatic design changes to trade unions and employer organisations (Vis and Van Kersbergen 2013).

Finally, scholars also have investigated the extent to which economic crises help or hinder the adoption of reforms. On the one hand, in crisis times voters may find the social safety net to be more valuable than otherwise (Vis et al. 2011; Galasso 2014). On the other hand, politicians can use a budgetary crisis to avoid blame for unpopular reform initiatives (see, e.g., Vis 2016). Furthermore, if voters punish politicians for an economic downturn (retrospective economic voting), elected officials may be more likely to pursue unpopular reforms because reelection already is less likely (Hollanders and Vis 2011). Empirically, studies tend to confirm that crises facilitate the adoption of reforms (Pitlik and Wirth 2003; Agnello et al. 2015).

Our dataset allows us to complement this large body of literature as follows. First, given information on a large set of individual characteristics and a relatively large number of observations (over 12,000) we systematically can disentangle the marginal effects of various individual covariates mentioned above. Second, and importantly, we can trace the development of household preferences for reform over a ten-year time span. Our data start at the moment when fiscal subsidies for early retirement were being phased out and cover several years of political discussions about raising the retirement age, until its implementation in 2012. This time dimension plays a critical role, and although we cannot make bold statements about the causal impact of particular events, these time effects give us some suggestions on decisive moments in the public acceptance of reforms. 


\section{The Dutch public pension and the reform process}

The focus of this paper is the flat-rate public pension system (Algemene Ouderdomswet, "AOW"), which is financed on a pay-as-you-go basis. In addition to the AOW, almost $90 \%$ of all workers are covered by a funded earnings-related occupational pension that takes the AOW benefits into account in their pension plans. At the start of the AOW in 1957, the statutory retirement age was set at 65 . Yet, until the early 2000s most workers left the workforce sooner, supported by fiscal incentives with the ill-guided goal of releasing jobs for the young (Gruber and Wise 2010). In the meantime, demographic tensions put ever more pressure on PAYG. The old-age dependency ratio rose from just below $16 \%$ in 1957 to $20 \%$ in $1985,25 \%$ in 2010 and $30 \%$ in 2015 . That demographic trend was not unanticipated and already at the time the AOW was created, the finance minister noted that, "should the burden become too heavy in the future, then relief is possible by raising the statutory age of retirement, an option that well suits the increase of the average age and a better physical condition of the elderly". ${ }^{2}$ Yet, it was not until more than 50 years later, in 2009, that the Dutch government seriously proposed raising the retirement age.

To appreciate the reform process, some features of the Dutch political processes are worth mentioning. The Netherlands has a multi-party system wherein coalition governments generally consist of two or three parties. In the period under study (2003-2013), six different coalition governments were in place, consisting of one or two central parties (the Christian-democrats, conservative liberals and social-democrats) and, typically, the support of one smaller party either to the left or right. According to Green-Pederson (2002), the centrist parties facilitated the emergence of inter-party policy consensus, thereby reducing the risk that parties' justifications for retrenchment would be challenged by other parties. It is also worth noting that labor unions and employer organizations (together dubbed as "social partners") are consulted by the government on major socioeconomic reforms. The government is obliged to give a formal appreciation of the proposals made by a tripartite body of trade unions, employer organizations and independent experts, the Social and Economic Council (SER). That requirement also applies to the reports of other important advisory bodies, such as the Scientific Council for Government Policy (WRR) and the Bureau for Economic Policy Analysis (CPB), who play important roles in analyzing the economic and budgetary effects of reforms under discussion (Visser and Hemereijck 1998; Den Butter and Mosch 2003).

Raising the retirement age has been on the political agenda on several previous occasions. In the mid-1980s a high-level committee advised raising the retirement age (Drees Committee 1987). In 1993, the WRR echoed this advice (WRR 1993). However, political parties were not keen on proposing changes to the AOW and instead resorted to more passive reforms, such as raising employees' and employers' contributions-and since the late 1990s, transfers from the general budget-and suspensions of the policy of indexing pension benefits. According to Green-Pederson (2002), one reason why no serious reforms were put on the table in the pension sphere, as opposed to other contentious policy domains, was that the dominant discourse for retrenchment in the 1990s was to combat retirement before the statutory age.

In the 2000s raising the retirement age received renewed attention. In 2006, well before the financial crisis, both CPB, WRR and a high-level committee of civil servants issued

${ }^{2}$ Own translation of Explanatory Memorandum, Kamerstukken II 1954-1955, 4009, No. 3, chapter 8. 
reports on the budgetary costs of population ageing, several of which hinted at raising the retirement age. In the general elections later that year, raising the retirement age for the first time featured in two party platforms - by the smaller social-liberal party and the Green party. Furthermore, in November 2007, the minister of Social Affairs invited a high-level committee to propose measures to strengthen labor-market participation (Bakker Committee). In June 2008 this committee advised gradually raising the retirement age to 67 in 2040. In its official response later that month, the responsible minister concurred that raising the retirement age "seemed inevitable" (in 1993 he had in fact chaired the WRR Committee that had advised raising the statutory retirement age gradually). Yet, he maintained that the government's stance was to "avoid this inevitability" by, e.g., raising labor-market participation rates before the age of 65 and improving public finances by other means.

In 2009, the government did propose raising the retirement age as part of a reform package to weather the economic crisis, but it took some time before the measure was finally agreed upon. After protests by the main trade union federation, social partners were first invited to formulate an alternative that would realize the same budgetary gains. Partly owing to strong opposition from the trade unions' constituencies, they failed to deliver by their deadline of October 1. A few days later, the government proposed raising the retirement age to 66 in 2020 and to 67 in 2025. However, in early 2010 the coalition government fell and social partners again started to negotiate in anticipation of new government plans. In early June of that year, several days before the elections, they reached an agreement to raise the retirement age in one step to 66 in 2020 and-if needed-to 67 in 2025. The new (minority) government supported that plan, even though it relied on the support of a populist party (PVV) that had opposed the reform strongly before the elections. ${ }^{3}$ The final act of the reform process started in spring 2012, when the government had to pursue consolidation measures to comply with European budgetary rules. With the support of two other parties, the government proposed raising the retirement age in small increments already in 2013. It was this 'Spring Agreement' that was finally implemented.

A preceding series of reforms is also worth mentioning. Given the high frequency of early retirement, a previous step involved ending fiscal subsidies for such action. In the early 2000s, the government first suggested phasing out fiscal subsidies, while starting negotiations with social partners. After massive trade union protests in October 2004, social partners and the government struck a deal to end subsidies for early retirements, using lenient transition periods to limit the costs for the trade unions' older constituents.

Figure 1 summarises the most heated debates in the reform process, highlighting Google search activity on some key related search terms. A first peak occurs in summer 2005, when following the phasing out of fiscal subsidies for early retirement schemes, trade unions and the government reached an agreement on a transition scheme for civil servants (see De Grip et al. 2011). Furthermore, in September 2006 search activity for "ageing" reaches a peak, just after the publication of several reports on the impact of ageing on social safety net programs (see above). Furthermore, search activity on the "statutory retirement age" peaks in October 2009, after social partners failed to propose an alternative to raising the retirement age. Finally, searches for "retirement age" peak in November 2012, following the 2013 launch of an awareness publicity campaign.

\footnotetext{
3 Some powerful members of the main trade union federation (Federatie Nederlandse Vakbeweging, "FNV") remained opposed to this agreement and demanded the resignation of the federation leader, which happened in 2012.
} 


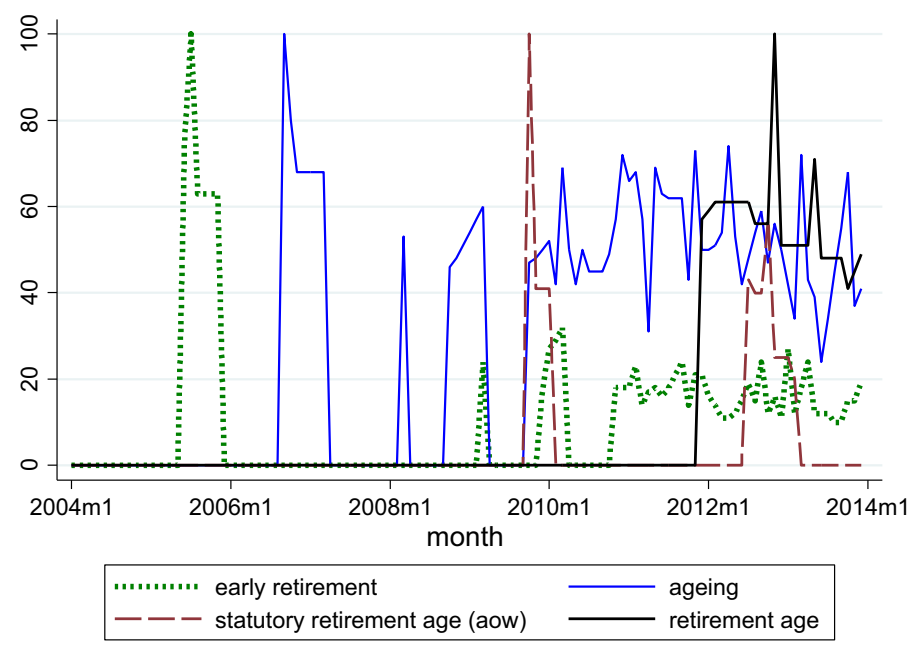

Fig. 1 Monthly Google search activity, 2004-2013. Note: Each line shows the relative search activity on the respective term over time. A peak of 100 indicates when in the 2004-2013 period the term was used most Source: Google trends (available from January 2004)

\section{Data}

We use data from the DNB Household Survey ("DHS"), conducted by CentERdata at Tilburg University. The panel includes approximately 2000 households, which are representative of the Dutch population, from which one or more household members take part. A majority of respondents participates in the panel year after year; in case of attrition, new participants with similar characteristics are recruited. The survey includes questions on demographics, occupational status, education, earnings, wealth, health and psychological concepts, in various modules spread out over the year. Among other things, the panel has been used to study financial market and savings behavior (see, e.g., Guiso et al. 2008).

Our main area of interest concerns respondents' answers to a question on reforming the public pension scheme, which has been posed since 2004: "To make sure that the general old-age pension remains affordable certain measures have to be taken. Which of the following measures appeals to you most?" Three answers are possible: (1) "a lower general old-age pension at the age of 65", (2) "an increase of the old-age pension premium for people working", and (3) "increase the age by two years (from 65 to 67 years of age) at which one will receive the general old-age pension". ${ }^{4}$ Respondents could list both a first and a second option. As discussed above, we are mostly interested in the attitude of respondents towards an increase in the retirement age (option iii). Unlike the other two measures, the retirement age has an important reference value in retirement decisions (Sect. 2). Furthermore, while in the past policymakers had resorted to both raising contributions and cutting benefits, politicians started to seriously consider raising the retirement age only in the late 2000s (see Sect. 3). In addition, as an auxiliary variable we will also analyze respondents' expected retirement ages (available from 2003), as that answer can help complement our understanding of the reform process. For instance, if

\footnotetext{
${ }^{4}$ In 2012 - when the government had decided to raise the statutory retirement age- the last option was asked without reference to 65 and 67; in 2013, reference is made to the recent increase in the statutory retirement age.
} 
respondents over the years systematically expect to work longer, this may indicate that they are aware of (or expect) policy adjustments. The wording of the question is: "At what age do you expect to retire, or make use of the early retirement arrangement?".

Table 1 reports summary statistics for our dataset. The first variable, preference_aowage_up, is a dummy taking the value of 1 when the respondent lists raising the retirement age as the first preferred option for AOW reform (in Sect. 7, we will also discuss the results for the other reform options). On average, this comprises $29 \%$ of the observations. As to the second variable, expected_retirementage, the sample is smaller, as this question is not posed to all respondents. ${ }^{5}$ Table 1 shows that of those 9278 respondents listing an expected age of retirement, the average is 63.5. Table 1 also lists the summary statistics of all of our empirical models' explanatory variables. Before discussing the individual covariates, it must be noted that some values are missing. These missing values are associated with other modules of the questionnaire that respondents have not answered. Where possible, we have imputed missing values by entering the mean of the observations of the respondents from previous and following years when they participated in the same survey. This particularly applies to the psychological traits, which were not asked of respondents in all years. ${ }^{6}$ While at most $8 \%$ of values remain missing for a single variable, with all these missing values combined in our full model we end up with subsamples of $87 \%$ (in the case of the expected retirement age) and $89 \%$ (in the case of preferences for AOW reform) of the total sample. In Sect. 7, we test whether the treatment of missing values influences our results.

Turning to the individual covariates in Table 1, most are straightforward and have been used in other studies reviewed in Sect. 2 so we restrict our discussion to the less obvious ones at the bottom of the table. First and foremost, a unique feature of our dataset is the inclusion of respondents' scores on four personality traits, all of which have been constructed and validated in psychological research. For all four concepts, respondents need to rate (on a one-to-seven scale) the extent to which they agree with several statements (some are reverse coded). ${ }^{7}$ Table 1 reports the average score on all questions/statements. Although not all concepts have been linked systematically to PAYG reform, the literature reviewed in Sect. 2 offers inspiration for our hypotheses. First, following Alesina and La Ferrara (2005), we can expect risk averse individuals to attach more value to redistribution and, hence, to prefer raising payroll contributions over raising the retirement age (and over cutting benefits). The role of the statutory retirement age as a focal point is also likely to be more relevant for risk-averse individuals. On the other hand, patient individuals have been found more systematically to save some of their own earnings (Hastings and Mitchell 2011; Sutter et al. 2013). As such, the importance of the official retirement age as a focal point might be less important and they might be less opposed to a later retirement age.

\footnotetext{
5 In addition, some respondents indicate that the question is not applicable to them. We focus on respondents who are still active in the labor market or who still have not entered it. Furthermore, we report missing values in some rare cases for which the expected retirement age was below 40 (this does not influence our results).

${ }^{6}$ In 2003, none of the psychological concepts feature in the questionnaire. Furthermore, locus of control is not included in the years 2004, 2008, 2010 and 2012. Finally, starting from 2010, the module on patience is only asked to respondents who have not yet answered it. When applying a stricter imputation methodimputing missing values only with the value observed in the closest year this question was asked-our sample is reduced by around a third. In the regression of the expected retirement age some variables lose statistical significance (e.g., the dummies for the third wealth quartile, higher vocational training and risk aversion). All other results are largely the same.

7 The codebooks of all years are available at http://www.dhsdata.nl/.
} 
Table 1 Sample summary statistics, 2003-2013. Source: DHS 2003-2013

\begin{tabular}{|c|c|c|c|c|c|}
\hline & Count & Mean & $\mathrm{SD}$ & Min & Max \\
\hline \multicolumn{6}{|l|}{ Dependent variables } \\
\hline preference_aowage_up (D) & 13,723 & 0.29 & 0.46 & 0 & 1 \\
\hline expected_retirementage & 9278 & 63.51 & 3.78 & 40 & 98 \\
\hline \multicolumn{6}{|l|}{ Covariates } \\
\hline age & 14,722 & 46.31 & 11.61 & 16 & 65 \\
\hline employee (D) & 14,722 & 0.69 & 0.46 & 0 & 1 \\
\hline self_employed (D) & 14,722 & 0.06 & 0.24 & 0 & 1 \\
\hline household (D) & 14,722 & 0.09 & 0.29 & 0 & 1 \\
\hline benefits (D) & 14,722 & 0.12 & 0.32 & 0 & 1 \\
\hline other (D) & 14,722 & 0.04 & 0.20 & 0 & 1 \\
\hline grossincome (1000 EUR) & 14,003 & 32.50 & 24.20 & 0 & 582.5 \\
\hline financial_wealth (1000 EUR) & 14,259 & 30.90 & 83.23 & -68.9 & 3702.1 \\
\hline female (D) & 14,722 & 0.46 & 0.50 & 0 & 1 \\
\hline married (D) & 14,722 & 0.64 & 0.48 & 0 & 1 \\
\hline child (D) & 14,722 & 0.54 & 0.50 & 0 & 1 \\
\hline grandchild (D) & 14,722 & 0.13 & 0.33 & 0 & 1 \\
\hline health & 14,322 & 3.90 & 0.67 & 1 & 5 \\
\hline university (D) & 14,722 & 0.18 & 0.38 & 0 & 1 \\
\hline vocational_high (D) & 14,722 & 0.29 & 0.45 & 0 & 1 \\
\hline vocational_intermediate (D) & 14,722 & 0.21 & 0.41 & 0 & 1 \\
\hline preuniversity (D) & 14,722 & 0.09 & 0.29 & 0 & 1 \\
\hline low (D) & 14,722 & 0.23 & 0.42 & 0 & 1 \\
\hline riskaversion & 13,900 & 5.25 & 1.00 & 1.3 & 7 \\
\hline patience & 14,089 & 4.13 & 0.58 & 1.5 & 6.8 \\
\hline conscientiousness & 14,085 & 4.42 & 0.58 & 1.8 & 5.8 \\
\hline locus_of_control & 13,503 & 4.55 & 0.63 & 1.8 & 7 \\
\hline frequency & 14,722 & 3.51 & 2.54 & 1 & 11 \\
\hline
\end{tabular}

In 2003 respondents were inquired about their expected age of retirement (999 observations) but not yet about their preferences for AOW reform. (D) denotes a dummy variable

Third, as noted in Sect. 2, conscientious individuals attach more value to keeping obligations and display stronger support for the status quo (no change to the retirement age). Also, given the role of the retirement age as a focal point for retirement, we expect more conscientious individuals to display less support for postponing that age. Fourth, locus of control measures the extent to which an individual believes in his or her own control over lifetime economic outcomes, in contrast to having those outcomes determined by luck or fate. Following Alesina and Giuliano (2009) and Kouba and Pitlik (2014), such individuals can be expected to attach less value to redistribution and, hence, to prefer raising the retirement age (or cutting benefits) over raising contributions. As with patience, the official retirement age as a focal point might be less important.

The last row of Table 1 shows that respondents on average participated in 3.5 surveys ('frequency'), while some individuals even participated over the entire period (11 years). 
This feature of the data allows us to correct for the possibility that year effects are driven by changes in the composition of the sample. ${ }^{8}$ On the other hand, it is also possible that individuals who remain in the panel are 'treated' by answering this question several times. We will test for these possibilities in Sect. 7.

Finally, a crucial dimension of our dataset is that we can trace households' expectations and preferences over ten years. Focusing on preferences, the first panel of Fig. 2 shows the first preferred option of respondents for ensuring sustainability of the public pension scheme. The figure shows a gradual increase in support for a higher retirement age. This greater support for raising the retirement age came especially at the expense of support for raising payroll tax premiums; the support for lower benefits remained remarkably constant at around 20\%. In 2013, when the statutory retirement age was raised, support for a further increase in the retirement age dropped, although saying at a higher level than in 2004. The second panel of Fig. 2 lists the support for raising the retirement age as respondents' first, second and last option. When the second preferred option also is entered, support for raising the retirement age increased from more than $40 \%$ in 2004 , to more than $70 \%$ in 2012 .

\section{Regression results}

\subsection{Specification}

We will now assess the impact of various covariates on both the expected retirement age and support for raising the retirement age. In both regressions, we enter the same characteristics as covariates, except the dummies for working in the household and receiving benefits; not all of those individuals are asked about their expected retirement age (see footnote 6). We pool observations on all respondents and years together, exploiting both variation between respondents and over time. We include year dummies in all regressions and cluster standard errors at the household level. The expected retirement age is a continuous variable and is estimated by OLS. The preference for raising the statutory retirement age is captured by a dummy variable $(1=$ postponing the retirement age is first preference for reform; $0=$ second or last preference) and is estimated with a probit regression, for which we report marginal effects at the variable's mean. In Sect. 7, we test whether those results are robust to a fixed effects panel regression of the individuals who take part in the survey for several years, as well as several other robustness checks.

Of all the covariates listed in Table 1, we clearly can expect some correlation. Most correlations are small and of the more than 200 pairwise correlations, only one exceeds 0.5 , the threshold often used as a rule of thumb for problems of multicollinearity. That correlation is between being married and having a child $\left(r^{2}=0.81\right)$. We decided not to enter the dummy for having a child, while we keep the dummy for being married and for having a grandchild. Furthermore, we test the stability of remaining coefficients by adding the various sets of covariates (age, occupational status, income/wealth, demographics, education and personality traits) one by one, in both directions. The results (not reported) reveal some cases for which regression coefficients and their significance levels fluctuate owing to the inclusion of other covariates; in most cases, coefficients and standard errors

\footnotetext{
${ }^{8}$ One concern is that until 2012, the mean age of respondents rose gradually. In 2013 , the average age dropped by several years, owing to CentER's oversampling of younger households to correct for the ageing of the sample in prior years.
} 

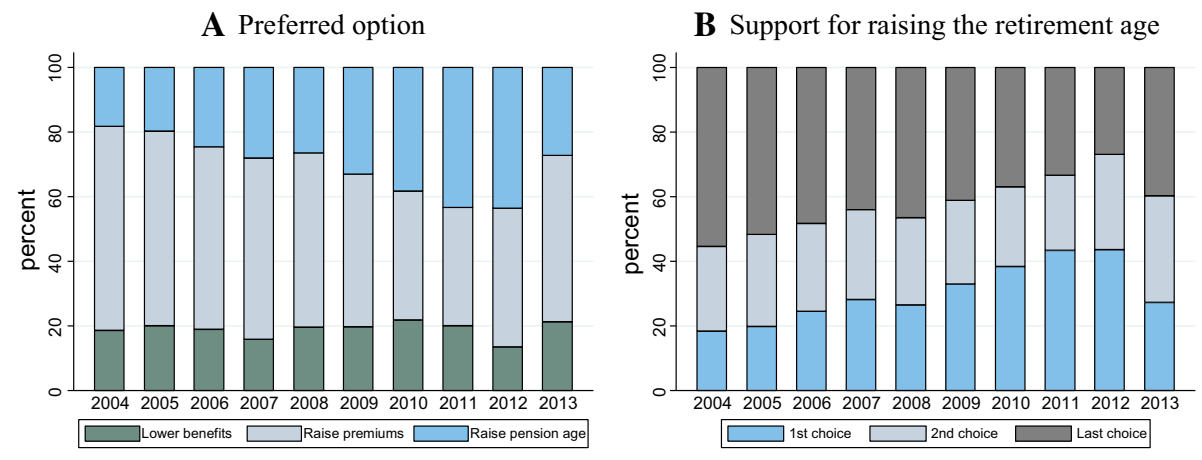

Fig. 2 Preferences for AOW reform. a Preferred option. b Support for raising the retirement age. Note: a shows the percentage of respondents listing each option as their first choice for AOW reform. $\mathbf{b}$ shows the percentage of respondents listing an increase in the retirement age as 1st, 2nd or last preferred reform option

remain stable throughout. In the case of preferences for reform, stability is observed, conspicuously, for the educational dummies, occupational status and the psychological traits.

Finally, we note some choices on the functional form of our regressors. First, we include age, income, wealth and education in dummy categories as they are not necessarily related linearly to expectations and preferences. Second, in line with Salamanca Acosta (2015), we standardize the scores on the psychology traits and on health so that they have zero mean and a standard deviation of one.

\subsection{Results}

The results of our two regressions are reported in Table 2. Coefficients for the time dummies are suppressed but will be discussed in the next section. We first discuss the results for age, which plays a dominant role in political economy models of PAYG reform. Several results stand out. First, respondents below 35 of age expect to retire significantly earlier than the reference group of the respondents, aged from 35 to 45 . This result could suggest that young households were more naïve in their assessments of future retirement policies. ${ }^{10}$ Preferences do not differ among the youngest respondents and the reference age group (35-45), while those aged between 45 and 55 report significantly less support for raising the retirement age than the younger respondents, in line with their economic interests. Interestingly, this finding does not hold for respondents aged 55-65. The relative indifference of this latter group to raising the retirement age might be explained by the fact that a significant share of them already is in early retirement. Alternatively, they may not be affected owing to the transition periods featured in the reform proposals.

\footnotetext{
${ }^{9}$ Note that we standardize variables by taking the mean and standard deviation per year. Although personality traits typically are assumed largely to be time-invariant, some evidence exists that they can fluctuate mildly, particularly when it comes to risk aversion (see chapter 2 of Salamanca Acosta 2015).

${ }^{10}$ When running the regression of the expected age of retirement in two sub-periods (before and after 2007) we find that in the first period young respondents (below 35 years of age) were expecting to retire significantly earlier than the reference group (35-45 years), while this effect is not statistically significant for the years after 2007. This is consistent with the idea that economic and political events gave young people, in particular, a 'wake-up call' on what future retirement policies they could expect.
} 
Table 2 Results baseline regression of retirement expectations and preferences for reform

\begin{tabular}{|c|c|c|}
\hline & $\begin{array}{l}\text { (1) } \\
\text { expected_retirementage } \\
\text { OLS }\end{array}$ & $\begin{array}{l}(2) \\
\text { preference_aowage_up } \\
\text { Probit }\end{array}$ \\
\hline \multicolumn{3}{|c|}{ Age (reference group: aged 35-45) } \\
\hline Below 35 & $\begin{array}{l}-0.48 * * \\
(0.23)\end{array}$ & $\begin{array}{l}-0.01 \\
(0.02)\end{array}$ \\
\hline Age $45-55$ & $\begin{array}{c}-0.19 \\
(0.16)\end{array}$ & $\begin{array}{l}-0.06^{* * * *} \\
(0.02)\end{array}$ \\
\hline Age $55-65$ & $\begin{array}{l}-0.21 \\
(0.18)\end{array}$ & $\begin{array}{l}-0.02 \\
(0.02)\end{array}$ \\
\hline \multicolumn{3}{|c|}{ Employment status (reference group: employees) } \\
\hline self_employed & $\begin{array}{l}0.35 \\
(0.37)\end{array}$ & $\begin{array}{l}0.10 * * * \\
(0.03)\end{array}$ \\
\hline household & & $\begin{array}{l}0.04 \\
(0.03)\end{array}$ \\
\hline benefits & & $\begin{array}{l}0.11 * * * \\
(0.02)\end{array}$ \\
\hline other & $\begin{array}{l}-0.52 \\
(0.37)\end{array}$ & $\begin{array}{l}0.02 \\
(0.03)\end{array}$ \\
\hline \multicolumn{3}{|c|}{ Income/wealth (reference group: $Q 1$ ) } \\
\hline incomeq2 & $\begin{array}{l}0.16 \\
(0.37)\end{array}$ & $\begin{array}{l}-0.01 \\
(0.02)\end{array}$ \\
\hline incomeq 3 & $\begin{array}{l}0.18 \\
(0.37)\end{array}$ & $\begin{array}{l}-0.01 \\
(0.02)\end{array}$ \\
\hline incomeq4 & $\begin{array}{l}-0.36 \\
(0.39)\end{array}$ & $\begin{array}{l}-0.02 \\
(0.03)\end{array}$ \\
\hline wealthq2 & $\begin{array}{l}-0.15 \\
(0.19)\end{array}$ & $\begin{array}{l}-0.02 \\
(0.02)\end{array}$ \\
\hline wealthq3 & $\begin{array}{l}-0.41 * * \\
(0.19)\end{array}$ & $\begin{array}{l}-0.02 \\
(0.02)\end{array}$ \\
\hline wealthq4 & $\begin{array}{l}-0.77 * * * \\
(0.19)\end{array}$ & $\begin{array}{l}-0.03 \\
(0.02)\end{array}$ \\
\hline \multicolumn{3}{|l|}{ Demographics } \\
\hline female & $\begin{array}{l}-1.01 \text { *** } \\
(0.15)\end{array}$ & $\begin{array}{l}-0.02 \\
(0.01)\end{array}$ \\
\hline married & $\begin{array}{l}-0.73^{* * *} \\
(0.16)\end{array}$ & $\begin{array}{l}-0.03 * * \\
(0.02)\end{array}$ \\
\hline grandchild & $\begin{array}{l}0.12 \\
(0.23)\end{array}$ & $\begin{array}{l}0.04 * \\
(0.02)\end{array}$ \\
\hline health_standardised & $\begin{array}{l}0.20 * * * \\
(0.08)\end{array}$ & $\begin{array}{l}0.02 * * * \\
(0.01)\end{array}$ \\
\hline \multicolumn{3}{|c|}{ Education (reference group: low education) } \\
\hline university & $\begin{array}{l}0.78 * * * \\
(0.25)\end{array}$ & $\begin{array}{l}0.11 * * * \\
(0.02)\end{array}$ \\
\hline vocational_high & $\begin{array}{l}0.57 * * * \\
(0.22)\end{array}$ & $\begin{array}{l}0.02 \\
(0.02)\end{array}$ \\
\hline vocational_intermediate & $\begin{array}{l}-0.17 \\
(0.22)\end{array}$ & $\begin{array}{l}-0.01 \\
(0.02)\end{array}$ \\
\hline
\end{tabular}


Table 2 continued

\begin{tabular}{lll}
\hline & $(1)$ & $(2)$ \\
& $\begin{array}{l}\text { expected_retirementage } \\
\text { OLS }\end{array}$ & $\begin{array}{l}\text { preference_aowage_up } \\
\text { Probit }\end{array}$ \\
\hline preuniversity & 0.24 & -0.00 \\
Personality traits & $(0.29)$ & $(0.03)$ \\
riskaversion_standardised & & \\
patience_standardised & $0.12^{*}$ & $-0.02^{* * *}$ \\
& $(0.07)$ & $(0.01)$ \\
conscientiousness_standardised & 0.07 & $0.02 * *$ \\
& $(0.08)$ & $(0.01)$ \\
locus_of_control_standardised & $-0.17 * * *$ & $-0.01 * *$ \\
& $(0.07)$ & $(0.01)$ \\
ccons & -0.13 & $0.02 * * *$ \\
N & $(0.08)$ & $(0.01)$ \\
(Pseudo) $R^{2}$ & $63.45^{* * *}$ & \\
Time dummies & $(0.49)$ & 12176 \\
\hline
\end{tabular}

In parentheses we report standard errors, which are clustered at the household level. For the probit regression (column 2) we report marginal effects measured at the mean. Pseudo $R^{2}$ is McFadden's

$* p<0.10 ; * * p<0.05 ; * * * p<0.01$

The results furthermore show that occupational status matters for reform preferences (but not for expectations). Current employees (the reference group) not surprisingly are most hostile to raising the retirement age, while the self-employed and respondents who receive benefits (for either disability or for retirement) are significantly more favorable toward raising the statutory retirement age. Those effects are rather large (10 and 11 percentage points, respectively). Self-employed respondents might be particularly hostile to higher payroll contributions, as fiscal illusion plays less of a role in their situations. Respondents who receive (disability or old-age pension) benefits might worry about the benefit level of their pensions and the eroding support for larger pension contributions among the active workforce (in Sect. 7, we report results from probit regressions on the other two reform options, confirming that both groups are especially concerned about larger payroll contributions). Finally, income and wealth do not seem to matter, ${ }^{11}$ except for respondents in the two highest wealth quartiles, who expect to retire significantly earlier than respondents in the quartile with the lowest wealth (including negative wealth).

Turning to demographic factors, females expect to retire a year earlier than men. This can be explained by women having older partners and planning to retire at the same time. Married respondents also expect to retire earlier and also are significantly more hostile to raising the retirement age. Having grandchildren, however, strengthens support for

\footnotetext{
11 Note that 'wealth' potentially suffers from endogeneity, as private savings can be tapped for earlier retirement (although the most important pension savings-those in occupational pension schemes-are not included in this variable). We have run the same regressions without the wealth dummies. The results are identical, except for the estimated coefficients on some age dummies in the OLS regression of the expected retirement age, whereby the dummies for older respondents seem to pick up wealth effects.
} 
postponing the statutory retirement age (though only at the $10 \%$ level). This finding can indicate that respondents with grandchildren attach more importance than others to the future sustainability of the pension scheme. Furthermore, healthier respondents expect to retire at older ages and, hence, more often support raising the statutory retirement age.

Furthermore, with respect to education, respondents who attended university or a higher-level vocational training expect to retire nine and seven months later than others. Interestingly, support for raising the retirement age is 11 percentage points higher among university graduates than the lowest-educated respondents, but not significantly more or less than among other educational groups. In line with the discussion in Sect. 2, university graduates might be more supportive of a later retirement age because of greater job satisfaction, but also because of more knowledge about the budgetary pressures of an ageing population (note that income is held constant).

The last lines of Table 2 show regression results for our four measures of personality traits, which are in line with our hypotheses outlined above. First, risk-averse respondents are less supportive of raising the retirement age. Second, conscientious individuals expect to retire earlier and also are less supportive of raising the retirement age. Furthermore, patience and locus of control also matter for reform preferences. To be precise, someone who has one standard deviation more locus of control (patience) than the average, is $2 \%$ more likely to support postponing retirement.

\subsection{Goodness of fit}

The goodness of fit of our models is not very high, as is often the case with this kind of survey data (see, e.g., Boeri et al. 2001, 2002, 2012; Blinder and Krueger 2004). Clearly, it is difficult to attribute expectations and preferences to observed characteristics even with a rich set of respondent characteristics. Still, we have identified above many factors that affect expectations and preferences significantly. Table 3 summarises the goodness of fits of both models and the explanatory shares that can be attributed to various subsets of

Table 3 Decomposition goodness of fit

\begin{tabular}{llllll}
\hline & \multicolumn{2}{l}{ (1) Expectations } & & \multicolumn{2}{l}{ (2) Preferences } \\
\cline { 2 - 3 } & $\mathrm{R}^{2}$ & \% of full model & & Pseudo $R^{2}$ & \% of full model \\
\hline Age &. &. &. & 0.003 & 6.3 \\
Occupational status &. &. & 0.007 & 13.2 \\
Income/wealth & 0.009 & 7.3 &.. &.. \\
Demographic & 0.020 & 16.4 & & 0.002 & 3.8 \\
Education & 0.008 & 6.6 & & 0.008 & 15.0 \\
Personality & 0.003 & 2.5 & 0.006 & 11.4 \\
Time & 0.081 & 67.2 & & 0.027 & 50.4 \\
Total & 0.120 & 100.0 & & 0.054 & 100.0 \\
\hline
\end{tabular}

Contribution to goodness of fit of statistically significant regressors in models presented in Table 2

Decomposition of goodness of fit of the regressions of the expected retirement age and support for a an increase in the retirement age, including only those regressors that where statistically significant (see text and footnote 12). The (pseudo) $R^{2}$ is decomposed using the Shorrocks-Shapley method (calculated with Stata's 'shapley2' command, see Chávez Juárez 2015) 
covariates, focusing on those that are statistically significant at the $5 \%$ level. ${ }^{12}$ The regressors' shares in the total $\mathrm{R}^{2}$ are calculated using the Shorrocks-Shapley decomposition (Chávez Juárez 2015). For both the expected retirement age and preferences for PAYG reform, the year fixed effects clearly are the strongest predictors (67 and 50\%, respectively). Furthermore, demographic factors explain most of the remaining variation in the expected retirement age, followed by income/wealth and education. As for reform preferences, education, occupational status and personality traits account for most of the remaining variation, while age and demography play a more limited role. ${ }^{13}$

\section{Focus on the year fixed effects}

Figure 2 already indicated that support for raising the retirement age displayed an upward trend in the 2004-2013 period. In fact, in our regressions, the year fixed effects account for $67 \%$ of the explained fit of the model of the expected retirement age, and $50 \%$ of the explained fit of the preferences for AOW reform. It is therefore informative to look at the coefficients for the time dummies in greater detail. Unfortunately, with ten survey events it is difficult to attribute differences in the coefficients of the year dummies to particular events econometrically. Our approach, hence, is qualitative. We first plot the coefficients, identify some key patterns and then assess what possible explanations would fit these.

Figure 3 shows the coefficients of the year dummies of the regression explaining the expected retirement age (Panel A) and support for raising the retirement age (Panel B). Note that the base year of the year dummies is 2004 (2003 for the expected retirement age) and that the regression controlled for all the statistically significant covariates discussed above (as in Table 3). Furthermore, in addition to the confidence bands, we also have tested whether the estimated year coefficients differed statistically significantly from the previous year. That is the case for all years on the $\mathrm{x}$-axis marked in black and are of the largest magnitudes (i.e., in the left panel, the coefficients for 2003-2004 and 2004-2005 do not differ statistically, but those for 2005-2006 and later do). Lastly, in the interpretation of the year coefficients, it is informative to know that the surveys were administered in April/ May every year.

The panels display some interesting patterns. First, the first panel of Fig. 3 shows that the expected age of retirement of the respondents was stable over the surveys of 2003-2005, but witnessed a continuous upward trend thereafter, for which the year-to-year increase was statistically significant. Second, support for raising the statutory retirement age (panel B) rose during 2005-2007, but halted in spring 2008, rising thereafter to stabilize in spring 2012. In the 2013 survey, support for a further postponement of the retirement age dropped significantly, although the level of support remained higher than in 2004-2005. Plotting the time pattern for different subgroups (not reported) actually yields

\footnotetext{
12 In the OLS regression of the expected retirement age, we omitted all dummies for age and occupational status - which according to an F-test were not jointly significant, the dummy variable 'grandchild' and all personality traits except conscientiousness. In the probit regression for support for raising the retirement age, we omitted all dummies for income and wealth — which according to an F-test were not jointly significant, the dummy variables 'female' and 'grandchild'.

13 Due to collinearity the gross contributions to overall variation (i.e., when not including controls) of these factors can be higher. For instance, when looking at the contribution of age to reform preferences without controls, its contribution increases to $8.9 \%$. Yet, in relative terms the explanatory power of age still ranks 6 th after the year dummies, education, personality, occupational status and demographic factors. The results are also by and large the same when we exclude the year 2013, when the reform was already implemented.
} 
A Expectations

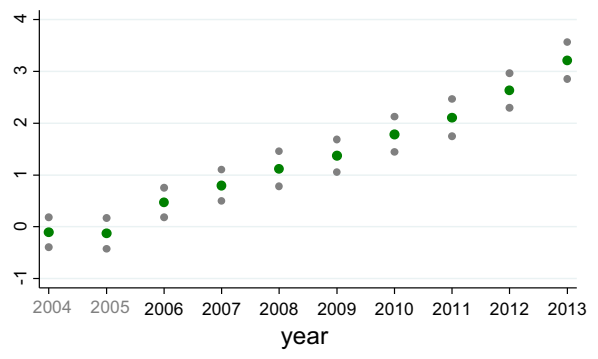

- Upper 95\% confidence limit

- Parameter estimate

- Lower $95 \%$ confidence limit
B Preferences

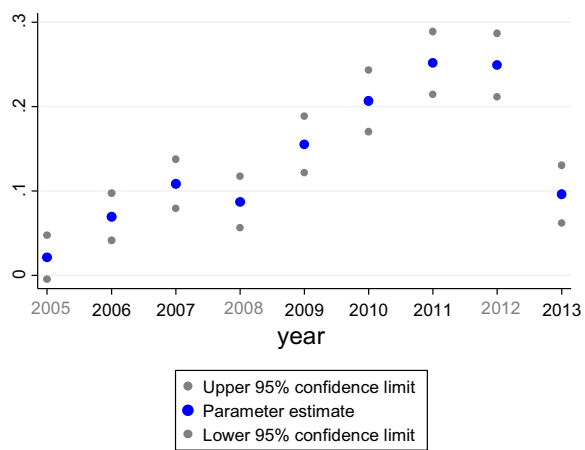

Fig. 3 Coefficients of the year dummies. a Expectations. b Preferences. Note: a shows the coefficients of the year dummies from the regression of the expected age of retirement, $\mathbf{b}$ from the probit regression on preferences for AOW reform (base years are 2003 and 2004, respectively). Grey dots show lower and upper confidence bounds. When the years at the x-axis are marked black and are of the largest size, this indicates that the year coefficient differed statistically significantly from the previous year

very similar patterns, which suggests that events in this period influenced the majority of respondents in the same way.

What factors can account for these patterns? In Sect. 3, we highlighted some key events in the reform process. Apart from those, economic conditions could also play roles. First, given that some of Dutch PAYG pensions are paid from the general budget, worsening economic conditions and public finances might influence respondents' expectations and preferences for AOW reform. Second, as the first and second pillar pensions are linked (see Sect. 3), it is possible that funding problems in the second pillar affect attitudes towards the PAYG system. Table 4 therefore provides an overview of economic conditions just before

Table 4 GDP, government debt and second pension pillar funding rate, 2003q1-2013q1. Source: Statistics Netherlands and De Nederlandsche Bank

\begin{tabular}{llll}
\hline Quarter & GDP growth & Government debt & Second pillar funding rate \\
\hline $2003 q 1$ & 0.9 & 49.3 & 114 \\
$2004 q 1$ & 1.1 & 50.3 & 121 \\
$2005 q 1$ & 1.3 & 49.4 & 134 \\
$2006 q 1$ & 3.1 & 48.3 & 144 \\
$2007 q 1$ & 3.6 & 44.7 & 140.9 \\
$2008 q 1$ & 3.6 & 43.3 & 132.3 \\
$2009 q 1$ & -4.2 & 57.3 & 91.8 \\
$2010 q 1$ & 0.1 & 57.3 & 108.2 \\
$2011 q 1$ & 2.6 & 59.1 & 111.8 \\
$2012 q 1$ & -1.6 & 62.2 & 98.6 \\
$2013 q 1$ & -0.9 & 66.4 & 106.5 \\
\hline
\end{tabular}

Year-on-year quarterly growth rate of GDP, government debt as percentage of GDP and the average funding rate of Dutch second pillar pensions as percentage of liabilities (for years 2003-2006 only annual figures were available) 
our surveys were conducted (in the first quarters of every year). It shows that until the 2008 survey, overall economic conditions were developing favorably. Between the 2008 and 2009 surveys, however, GDP dropped substantially and, in consequence, the debt-to-GDP ratio also worsened. Furthermore, the financial positions of second pillar pension funds worsened significantly because of large investment losses, falling interest rates and upward revisions in life expectancy at retirement.

Combining Figs. 1, 3 and Table 4 allows us to speculate on the factors that could cause the coefficients of the year dummies for respondents' preferences to trend upward. First, greater support for raising the retirement age in the years 2005-2007 is likely related to public discussions around the phasing out of the Dutch early retirement scheme-including the public attention to the reform of the early retirement scheme for civil servants in summer 2005-and public reports on societal ageing in 2006. Second, Google search activity on ageing and retirement issues was relatively subdued in 2007-2008, which might help explain why the increase in support for a later statutory retirement age ended in early 2008. ${ }^{14}$ Third, the gradually rising support for postponing the retirement age after the global financial crisis hit probably owes to a combination of greater awareness of fiscal constraints and more intense public discussions. Finally, after the raising of the statutory retirement age had been decided upon and communicated publicly, respondents expected to retire even later than they had beforehand. At the same time, support for postponing the statutory retirement age further fell, although it remained at levels higher than in 2004-2005.

\section{Sensitivity analysis}

This section describes several checks on the robustness of the results obtained above. The output of the first test is reported in the online appendix; all other empirical results are available upon request.

A first concern is that sample attrition is non-random. While we can correct for respondents' observed characteristics, those who participated more than once might also differ on characteristics that we cannot detect. Hence, it is possible that the year fixed effects pick up compositional changes in our sample. To check this, we can exploit the fact that a majority of respondents took part in the survey several times and estimate the timewise fixed effects with a panel regression wherein we can single out all time-invariant attributes. Figure A.1 in the appendix compares the coefficients of the year dummies reported above with those resulting from this fixed effects panel regression. Although coefficients differ somewhat, the time patterns described above are the same.

Second, it is possible that the missing values that result from merging the data from various survey modules affect our results. For instance, individuals participating in all surveys could be particularly interested in financial matters, whether private or public. As a robustness check, we compare the stability of coefficients as we add variables one by one, keeping the sample stable $(\mathrm{N}=8103$ and $\mathrm{N}=12,176$, respectively). The results show no changes in coefficient estimates or significance levels. Hence, we do not find evidence that the merging process influences our results.

Third, it also is possible that respondents are 'treated' by answering our questions. For instance, when respondents are required to think about options for AOW reform several

${ }^{14}$ On the basis of newspaper analysis, Van der Wiel (2009) confirms that in this period public discussions of old age pensions had virtually stopped. 
times, they could develop concerns about the scheme's sustainability. When the 'frequency of participation' of respondents is entered (see law row in Table 1) in our regression, we do not find evidence of such a 'treatment effect'.

Fourth, we assess the extent to which the year 2013 matters for our conclusions. A rise in the retirement age had been adopted in 2012; hence, at the time of the 2013 survey respondents faced a new situation (in the survey, the question was updated accordingly; see footnote 5). Furthermore, in 2013, larger proportion of young people participated in our survey (see footnote 9), who might also differ on non-observable characteristics. However, when 2013 is excluded from the sample, our results essentially are the same.

Fifth, we focused above on support for raising the statutory retirement age. Respondents also could report their support for two other reform margins, namely cutting retirement benefits and raising payroll "contributions". Our focus was motivated by the fact that in the period under study, raising the statutory pension age was the most salient reform option, both economically and politically (see also Sects. 1, 3 and 4). Yet, the interpretation of our results could be influenced by changes in preferences regarding the two other options. Therefore, we also ran similar probit regressions for them. Overall, the results indicate that more support for postponing the statutory retirement age came especially at the expense of support for larger payroll taxes. This conclusion first of all applies to estimates of the year coefficients. Corroborating Fig. 2, the coefficients of the year dummies of the probit regression explaining support for a later retirement age (Fig. 3, panel B) mirror almost perfectly those of the probit regression explaining support for raising contributions. Support for postponing the retirement age also comes at the expense of support for increasing payroll taxes when it comes to most individual covariates. Two notable exceptions are age and marital status. While respondents below 35 years of age and over 55 did not display significantly more or less support for a later statutory retirement age, the younger respondents were somewhat more favorable toward cutting pension benefits than the reference group, while the older respondents tended to favor raising payroll taxes. Furthermore, while married respondents were anxious about raising the retirement age, they tended to be indifferent towards the payroll taxes, but preferred reducing the level of public pension benefits.

\section{Conclusion}

Governments often find it hard to pursue economic reforms, even if they ultimately benefit a majority of voters. The literature is still divided on whether resistance to reform is explained mainly by distributional conflicts between different economic classes-for instance, dividing the young and the old in the case of pay-as-you-go public pension programs-or whether resistance to reforms is instead rather broad-based. Exploiting a unique longitudinal dataset, this paper has evaluated the explanatory powers of reform attitudes by means of a case study: the 2012 raising of the Dutch statutory retirement age from 65 to 67 .

Our most important findings can be summarised as follows. First, individual covariates were important drivers of reform attitudes, but not always as much as expected a priori. First and foremost, while age plays an important role in political economy models of PAYG reform proposals that postpone the statutory retirement age, it was not found herein to be a major dividing line. Respondents aged 45-55 did display relatively strong resistance to raising the retirement age, but that effect is smaller than those of some other 
covariates. The ages of respondents to annual surveys about pension-reform options explained only a small fraction of the observed variation in support for a two-year increase in the official retirement age. On the other hand, we find that at the individual level, education, employment status and personality traits appear to be the most robust drivers of acceptance of reform. Those factors all exert a significant impact on pension reform preferences, explain a fair share of the total variation among respondents, and the estimated coefficients were relatively insensitive to the inclusion of other explanatory variables. Especially for respondents' personality traits, this finding invites further theoretical and empirical work on the precise channels in play, as the literature on personality traits and policy preferences is still in its infancy.

Second, and what is most important, our year fixed effects explain most of the variation in respondents' expectations and preferences about policy reform. During the 2004-2013 period, public opinion gradually grew more favorable toward later retirement. Already in the years 2004-2006, when economic conditions and public finances were still benign, support for raising the retirement age grew steadily. We attribute this finding to the publication of various reports by independent agencies on the budgetary costs of ageing and to public discussions on the ending of subsidies for early retirement. When the global financial crisis set in, the Dutch government did for the first time propose postponing the statutory retirement age as part of a long-term budget consolidation package, igniting several years of public discussion. In those years, expectations and preferences continued to grow increasingly favorable towards working longer and retiring later. Estimating the year fixed effects by age cohorts confirms a gradual increase in support for that reform materialized among all age groups. These findings suggest that distributional clashes were not at the heart of the observed resistance to postponing the statutory retirement age in The Netherlands. Instead, we interpret our results as a collective learning process in which respondents gradually updated both their expectations and preferences on the statutory retirement age in response to new information and public debates.

Our research offers several guidelines for policymakers. First, in terms of the reform of social safety nets like publicly financed pensions, the most important challenge for reformminded policymakers seems to be to convince the public at large, rather than countering opposition from particular pressure groups who stand to lose the most. Second, our results underline the usefulness of reliable and easily understandable information on the financial position of the pension system. Such reports can convince the public of the need for reform and offer vote-seeking politicians an opportunity to justify unpopular public policy measures. Third, our results indicate that personality traits are important for public acceptance of reforms. Given that such traits largely are time-invariant, Kouba and Pitlik (2014) conclude that welfare state reforms can be facilitated only in the long run by educational and social policies that support the independence and self-confidence of people. Yet, appreciation of fundamental attitudes towards reform can offer some lessons in the short run as well. For instance, when people resist reforms because they feel they would lose control of their lives and livelihoods, policymakers should address those concerns by offering the public new perspectives in return. Finally, our results underscore the usefulness of incremental steps in the reform process. Although the Dutch government did propose raising the statutory retirement age only in 2009, the phasing out of early retirement schemes in 2004-2005 appears to have prepared households for a later retirement age as well. 
Acknowledgments I am grateful to Massimo Giuliodori, Diederik Dicou, Jakob de Haan, Jos Jansen, Ward Romp, Maarten van Rooij, William F. Shughart II, Barbara Vis, Frans van Winden, three anonymous referees and seminar participants at DNB, the European Department at IMF and the MInt group at the University of Amsterdam for useful comments and advice, to Kees Goudzwaard and Lans Bovenberg for sharing their experiences of the pension reform process and to Gareth Budden for copy editing the manuscript. The views expressed are the author's and do not necessarily reflect the official positions of DNB.

Open Access This article is distributed under the terms of the Creative Commons Attribution 4.0 International License (http://creativecommons.org/licenses/by/4.0/), which permits unrestricted use, distribution, and reproduction in any medium, provided you give appropriate credit to the original author(s) and the source, provide a link to the Creative Commons license, and indicate if changes were made.

\section{References}

Agnello, L., Castro, V., Tovar Jalles, J., \& Sousa, R. (2015). What determines the likelihood of structural reforms? European Journal of Political Economy, 37, 129-145.

Alesina, A., Ardagna, S. \& Trebbi, F. (2006) Who adjusts and when? The political economy of reforms. In IMF staff papers no. 53.

Alesina, A. \& Giuliano, P. (2009) Preferences for redistribution. In NBER working paper no. 14825.

Alesina, A., \& La Ferrara, E. (2005). Preferences for redistribution in the land of opportunities. Journal of Public Economics, 89(5-6), 897-931.

Arza, C., \& Kohli, M. (Eds.). (2008). The political economy of pensions: Politics, policy models and outcomes in Europe. London: Routledge.

Behaghel, L., \& Blau, D. (2012). Framing social security reform: Behavioral responses to changes in the full retirement age'. American Economic Journal: Economic Policy, 4(4), 41-67.

Blinder, A. \& Krueger, A. (2004) What does the public know about economic policy, and how does it know it? In NBER working paper no. 10787.

Boeri, T., Börsch-Supan, A., \& Tabellini, G. (2001). Would you like to shrink the welfare state? A survey of European citizens. Economic Policy, 16(32), 9-50.

Boeri, T., Börsch-Supan, A., \& Tabellini, G. (2002). Pension reforms and the opinions of European citizens. American Economic Review, 92(2), 396-401.

Boeri, T., \& Tabellini, G. (2012). Does information increase political support for pension reform? Public Choice, 150(1-2), 327-362.

Bonenkamp, J. \& Ter Reele, H. (2013) AOW + aanvullend pensioen: Nivellerend of denivellerend? Me Judice, 27 March 2013.

Brooks, C., \& Manza, J. (2006). Why do welfare states persist? Journal of Politics, 68(4), 816-827.

Browning, E. (1975). Why the social insurance budget is too large in a democracy. Economic Inquiry, 13(3), 373-388.

Buti, M., Turrini, A., Van den Noord, P. \& Biroli, P. (2008) Defying the 'Juncker Curse': Can reformist governments be re-elected? In European economy. Economic papers 324.

Caplan, B. (2007). The myth of the rational voter: Why democracies choose bad policies. Princeton: Princeton University Press.

Chávez Juárez, F. (2015). SHAPLEY2: Stata module to compute additive decomposition of estimation statistics by regressors or groups of regressors. Boston: Boston College.

Congleton, R., \& Shughart, W. F., II. (1990). The growth of social security: Electoral push or political pull? Economic Enquiry, 28(1), 109-132.

Cox, R. (2001). The social construction of an imperative: Why welfare reform happened in Denmark and the Netherlands but not in Germany. World Politics, 53, 463-498.

Cremer, H., Lozachmeur, J., \& Pestieau, P. (2008). Social security and retirement decision: A positive and normative approach. Journal of Economic Surveys, 22(2), 213-233.

Cremer, H., \& Pestieau, P. (2003). The double dividend of postponing retirement. International Tax and Public Finance, 10(4), 419-434.

Cukierman, A., \& Tommasi, M. (1998). When does it take a Nixon to go to China? American Economic Review, 88(1), 180-197.

De Grip, A., Lindeboom, M., \& Montizaan, R. (2011). Shattered dreams: The effects of change in the pension system late in the game. Economic Journal, 122(559), 1-25.

Den Butter, F. \& Mosch, R. (2003). The Dutch miracle: Institutions, networks and trust. Journal of Institutional and Theoretical Economics JITE, 59(2), 362-391. 
Drees Committee (1987) Gespiegeld in de tijd. De AOW in de toekomst, Ministry of Social Affairs and Employment, October 1987.

Drissen, E., \& Van Winden, F. (1991). Social security in a general equilibrium model with endogenous government behavior. Journal of Population Economics, 89, 89-110.

Eurobarometer (2012) Active Ageing, Special Eurobarometer 378, European Commission.

Fatas, E., Lacomba, J., \& Lagos, F. (2007). An experimental test on retirement decisions. Economic Inquiry, 45(3), 602-614.

Galasso, V. (2014). The role of political partisanship during economic crises. Public Choice, 158, 143-165.

Galasso, V., \& Profeta, P. (2002). The political economy of social security: A survey. European Journal of Political Economy, 18(1), 1-29.

Gerber, A., Huber, G., Doherty, D., \& Dowling, C. (2011). The big five personality traits in the political arena'. Annual Review of Political Science, 14, 265-287.

Goerres, A., \& Tepe, M. (2010). Age-based self-interest, intergenerational solidarity and the welfare state: A comparative analysis of older people's attitudes towards public childcare in 12 OECD countries. European Journal of Political Research, 49(6), 818-851.

Green-Pederson, C. (2002). The politics of justification: party competition and welfare-state retrenchment in Denmark and the Netherlands from 1982 to 1998. Amsterdam: Amsterdam University Press.

Gruber, J. \& Wise, D.A. (2010) (eds.) Social security programs and retirement around the world: the relationship to youth employment'. In NBER working paper no. 14647.

Guiso, L., Sapienza, P., \& Zingales, L. (2008). Trusting the stock market. The Journal of Finance, 63(6), 2557-2600.

Hastings, J. \& Mitchell, O. S. (2011) How financial literacy and impatience shape retirement wealth and investment behaviors. In NBER working paper no. 16740.

Hollanders, D., \& Vis, B. (2011). Voters' commitment problem and reforms in welfare programs. Public Choice, 155(3), 433-448.

Jansen, G., Evans, G., \& De Graaf, N. (2013). Class voting and left-right party positions: A comparative study of 15 Western democracies, 1960-2005. Social Science Research, 42, 376-400.

Jost, J., Federico, C., \& Napier, J. (2011). Political ideology: Its structure, functions, and elective affinities. Annual Review of Psychology, 60, 307-337.

Kohli, M. (2008). Generational equity: Concepts and attitudes, chapter 10. In C. Arza \& M. Kohli (Eds.), The political economy of pensions: Politics, policy models and outcomes in Europe. London: Routledge.

Kouba, L. \& Pitlik, H. (2014). I wanna live my life: locus of control and support for the welfare state. In Mendelu working papers in business and economics 46/2014, Mendel University in Brno.

Leroux, M., Pestieau, P., \& Racionero, M. (2011). Voting on pensions: Sex and marriage. European Journal of Political Economy, 27(2), 281-296.

Lumsdaine, R., Stock, J. \& Wise, D. (1996) Why are retirement rates so high at age 65? In Wise, D. (Ed.) Advances in the economics of aging, NBER Project Report.

Marier, P. (2005). Where did the bureaucrats go? Role and influence of the public bureaucracy in the Swedish and French pension reform debate'. Governance, 18(4), 521-544.

McGarry, K. (2002) Health and retirement: Do changes in health affect retirement expectations?' In NBER working paper no. 9317.

Mulligan, C. \& Sala-i-Martin, X. (1999) Gerontocracy, retirement, and social security. In NBER working paper no. 7117.

Niskanen, W. (1971). Bureaucracy and representative government. Chicago: Aldine-Atherton Publisher.

Olson, M. (1965). The logic of collective action: Public goods and the theory of groups. Cambridge: Harvard University Press.

Pierson, P. (1996). The new politics of the welfare state. World Politics, 48(2), 143-179.

Pitlik, H., Heinemann, F. \& Schweickert, R. (2014) Overcoming reform resistance and political implementation of large-scale welfare state reforms. WWW for Europe policy brief no. 3.

Pitlik, H., \& Wirth, S. (2003). Do crises promote the extent of economic liberalization? An empirical test. European Journal of Political Economy, 19(3), 565-581.

Salamanca Acosta, N. (2015) Economic preferences and financial risk-taking, Ph.D. dissertation Maastricht University, January 2015.

Scheubel, B., Schunk, D., \& Winter, J. (2013). Strategic responses: A survey experiment on opposition to pension reforms'. Scandinavian Journal of Economics, 115(2), 549-576.

Sinn, H., \& Uebelmesser, S. (2002). Pensions and the path to gerontocracy in Germany. European Journal of Political Economy, 19(1), 153-158. 
Sutter, M., Kocher, M. G., Glätzle-Rüetzler, D., \& Trautmann, S. T. (2013). Impatience and uncertainty: Experimental decisions predict adolescents' field behavior'. American Economic Review, 103(1), $510-531$.

Tabellini, G. (2000). A positive theory of social security. Scandinavian Journal of Economics, 102(3), 523-545.

Van der Wiel, K. (2009) Have you heard the news? How real-life expectations react to publicity. In IZA Discussion Paper No. 4064.

Van Els, P., Van den End, W. \& Van Rooij, M. (2003) Pensions and public opinion: a survey among Dutch households. In DNB Research Memorandum WO no 752/0341, De Nederlandsche Bank.

Verbon, H., \& Van Winden, F. (1985). Public pensions and political decision-making. De Economist, $133(4), 527-544$.

Vermeer, N., Van Rooij, M. \& Van Vuuren, D. (2014) Social interactions and the retirement age. DNB Working Paper No. 426.

Vis, B. (2016). Taking stock of the comparative literature on the role of blame avoidance strategies in social policy reform. Journal of Comparative Policy Analysis: Research and Practice, 18(2), 122-137.

Vis, B., \& Van Kersbergen, K. (2013). Towards an open functional approach to welfare state change: pressures, ideas and blame avoidance. Public Administration, 91(4), 840-854.

Vis, B., Van Kersbergen, K., \& Hylands, T. (2011). To what extent did the financial crisis intensify the pressure to reform the welfare state. Social Policy \& Administration, 45(4), 338-353.

Visser, J. \& Hemereijck, A. (1998) A Dutch miracle: job growth, welfare reform and corporatism in the Netherlands', Foreign Affairs, November/December 1998.

World Bank. (1994). Averting the old age crisis: Policies to protect the old and promote growth. Oxford: Oxford University Press.

WRR. (1993). Ouderen voor ouderen. Demografische ontwikkelingen en beleid, Scientific Council for Government Policy, March 1993. 